This item was submitted to Loughborough's Research Repository by the author.

Items in Figshare are protected by copyright, with all rights reserved, unless otherwise indicated.

\title{
Some important things to say about graphic design education [Editorial]
}

PLEASE CITE THE PUBLISHED VERSION

https://doi.org/10.1386/adch.16.1.3_2

PUBLISHER

Intellect

VERSION

AM (Accepted Manuscript)

\section{PUBLISHER STATEMENT}

This work is made available according to the conditions of the Creative Commons Attribution-NonCommercialNoDerivatives 4.0 International (CC BY-NC-ND 4.0) licence. Full details of this licence are available at: https://creativecommons.org/licenses/by-nc-nd/4.0/

\section{LICENCE}

CC BY-NC-ND 4.0

\section{REPOSITORY RECORD}

Harland, Robert G.. 2019. "Some Important Things to Say About Graphic Design Education [editorial]". figshare. https://hdl.handle.net/2134/28366. 


\section{Editorial}

\section{Some important things to say about graphic design education}

Robert Harland, Graphic Design Educators' Network

Considering the continued growth of undergraduate and postgraduate graphic design education in recent decades, as well as the considerable increase in newer subjects and programmes that utilize graphic design educational methods and tools - for example, communication design - it is bemusing that more has not been written about learning and teaching in graphic design. There are occasional articles in journals such as the one you are reading, and a handful of articles in published conference proceedings - for example, the biannual Design Research Society conferences - but a wider shared understanding of how the subject is taught is no further advanced than when Steven Heller pondered on the notion of a handbook' about how to teach graphic design two decades ago (1997: xiii). Then, his book, The Education of a Graphic Designer (1997), emphasized how we learn and teach the subject, comprising more than 40 relatively short essays, interviews and course syllabi, mostly from an American perspective. Not much has been added to this tome since.

This special issue of $\mathrm{ADCHE}$, about graphic design education, is, therefore, timely and emphasizes what is often referred to as pedagogic research. It draws from a wide geographic base, with contributions from America, Australia, Canada, Colombia, Italy, England and South Africa. This geographic spread confirms there is now more universal interest in what graphic design 
education is today, and how it is taught. The articles included here fall loosely into these two categories of interest.

The concentration of ideas, approaches and explanations - a publishing first for an academicjournal concerned with research in arts and media-based subjects in educational institutions - signals the potential for a more concerted effort in future that continues to demystify and expose how graphic design educators teach and how graphic design students learn. Recent evidence suggests that in future this topic is worth investing in. For example, the recently established Graphic Design Educators' Network (GDEN) in the United Kingdom, who has collaborated with Art, Design and Communication in Higher Education for this one-off edition, staged its second conference at Cardiff Metropolitan University in September 2016, following on from an inaugural event a year earlier at the University of Salford. Both of these gatherings attracted the interest of a hundred or so participants, all with an enthusiasm to share what they do and how they go about their work.

The theme of this special issue, 'Territories of Graphic Design Education', builds on the title of the Cardiff conference, called Exploring Territories. This idea is timely and has since stimulated the interest of the wider art and design education sector in the United Kingdom - for example, the Group for Learning in Art and Design (GLAD) whose 2017 conference is about Exploring Territories: The Changing Landscape of Art \& Design Higher Education. 
As a core subject within art and design, now seems to be the right time to reflect on a period of 'massification' (Burns et al. 2015: 200) in both the subject and in higher education generally, and consolidate the current state of affairs with regard to the global reach of learning and teaching in the subject. To support this endeavour, the nine articles included here provide a presentday perspective on aspects of graphic design education. Six of these contributions are concerned more with how learning and teaching happen in very different contexts. These tackle a range of practical and theoretical issues: language use; assessment feedback strategies; the dichotomy between design practice and design studies; encouraging critical reflection; and the teaching of semiotic theory. Three further articles concentrate on what the emphasis might be in graphic design education: provoking creative dissent; precarious working conditions; and a personalized reflection on what design must be.

In their article 'Underlying knowledge-knower structures in graphic design', Susan Giloi and Dina Zoe Belluigi explore the use of knowledge structuring theories for describing the fundamentals of graphic design pedagogy as a form of knowledge production. Working towards a unified vocabulary, and use of a 'theoretically grounded language', they concentrate on an important developmental challenge to verify the quality and purpose of student outputs. The article details a case-study approach for graphic design assessment practices. However, whereas Giloi and Belluigi concentrate more on the academics' application of language, Sue Perks and Nicola Whittingham concentrate on the international postgraduate students' acquaintance with and acquisition of English as a foreign language. Timelines in design: where 
linguistics meets design history' is a short work-in-progress report that describes a teaching support collaboration between a linguist and a graphic design lecturer, with the aim to improve the international students' 'skills in questioning, critical appraisal, evaluation and analysis'.

The difference between teaching how to do design compared with teaching how to study design is what preoccupies Deborah Littlejohn in her article, 'Disciplining the graphic design discipline: The role of external engagement, mediating meaning, and transparency as catalysts for change'. She blames the emphasis on preparing students for professional practice for restricting the subject's emergence as a serious academic discipline, but also reminds us that graphic design is in a continuous state of flux, in part due to the 'diverse networks of external engagement' that provide impetus for change.

Regardless of whether students do or study design, Irene Visser, Lisa Chandler and Peter Grainger concentrate on the role that assessment feedback strategies play in building confidence and creativity. 'Engaging creativity: employing assessment feedback strategies to support confidence and creativity in graphic design practice' dampens the student fixation on grades by emphasizing the importance of the teacher- student relationship and value of face-to-face feedback, despite institutional barriers working against this practice. Related to this, but with more emphasis on assessment tasks, Grant Ellmers' article 'Connecting learning from the graphic design project with thinking about approaches to design practice' concentrates on reflective practice and uses a case-study approach to highlight how critical reflection plays a role in connecting the kind of thinking associated with project work 
with their approach to practice through the 'principles of high- and low-road transfer'.

On a more philosophical note, in their article 'reflective didactic strategy to integrate semiotic theory and creative practice in graphic design education', Arturo de la Cruz and Mauricio Mejía are interested in how semiotics can be incorporated into design education. They do this by discussing the problems associated with teaching theory in institutions that do not make provision for this in their curriculum design. These institutions are claimed to be the 'ordinary design schools', meaning the 'majority' of institutions across the world that teach graphic design only through practical modules and without any provision for specialized theory input (the United Kingdom is acknowledged as an exception).

More concerned with what students learn in graphic design education, the final three articles present less familiar scenarios. Ironically, these collectively mirror a past when graphic design students associated more with art school culture, when the pioneers of the field forged a new professional practice by establishing their own working conditions and codes of practice, and many engaged with a more socially responsible agenda.

In '\#AlternativeArtschool // an interstitial space for creative dissent', Cathy Gale joins up an agenda for research with well-established theories for learning and teaching to present us with a case study that instils in students 'a more critical position [...] to inspire change through creative dissent'. The use of graphic design tools and methods, deployed in the service of provocation, 
are highlighted, and she shows how her approach is adapted for use with school children in what is described as a transformative experience.

Brave New Alps report on a series of international workshops with design students, design graduates and professional designers in the United Kingdom, Germany, Poland and Italy. This work-in-progress report, written up as Notes on design education and (prefigurative) work politics', explains an exploratory and practice-based multi-centric approach that emphasizes design education's need to address precarious work conditions in Europe. Similar to the concerns of de la Cruz and Mejía, who portray graphic design programmes that are neglectful of theory, Brave New Alps make a similar point about the aspects of professional practice, emphasized when they advocate 'discussing and passing on the tools of the trade', also raising questions such as 'what does an estimate look like and what should it include?' This, again, serves to emphasize the difference in approach to curriculum design across the international spectrum of provision.

The final article, from J orge Frascara, is a personal reflection that draws from a long-established academic career in visual communication design and information design. He speaks to the often overlooked 'design' in graphic design, perhaps in response to the subject's traditional emphasis on the 'graphic' in graphic design, or what he refers to as the 'visual elements'. 'Design, and design education: How can they get together?' emphasizes what design must be to develop its full potential, and provides a provocative, personalized and fitting finale to this special issue on graphic design education. 
In closing this opening editorial section, this special edition is part of other formative initiatives by GDEN to establish a space for reflection about learning and teaching in a subject that is fast moving, continually expanding and ever diversifying to meet student needs. It is the culmination of three years of work by a small group of graphic design educators, from whom a guest editorial board comprising myself, J ames Corazzo, Kirsten Hardie, Will Hill, Darren Raven and Catherine Smith was formed. The process of reviewing initial submissions, of which there were a surprising 27 in total, first went through a review process by the editorial team, before seventeen articles were sent out for a double-blind peer review - in some cases an article was read and reviewed a third time - undertaken by twenty independent reviewers from eight countries: America, Australia, Belgium, Brazil, Canada, England, Northern Ireland and Scotland.

The call for articles initially welcomed submissions that drew upon disciplinary practices to 'illuminate the lesser-lit ground of graphic design education', and in this pursuit I believe the editorial board members have achieved their aim. In making this happen the editorial team offer their sincere thanks to Professor Susan Orr for speculating on the suggestion that given the size, scope and strength of graphic design as a core subject in art and design education, graphic design educators might have some important things to say about graphic design education. Finally, Vicky Haverson also deserves a special mention for guiding a relatively inexperienced team through the process of journal production. I hope you enjoy reading this collection of articles as much as it has been rewarding to instigate, assemble and edit the 
content.

For further information about GDEN, visit

www.graphicdesigneducators.network

\section{References}

Burns, J ., Corazzo, J ., Harland, R., Hardie, K. and Raven, D. (2015), 'Graphic Design Educators' Network: Re-establishing the purpose and value of a graphic design subject association', Art, Design \& Communication in Higher Education, 14:2, pp. 199- 205.

Heller, S. (1997), The Education of a Graphic Designer, New York: Allworth Press. 